\title{
ВЕЩЬ В КУЛЬТУРЕ: К ИНТЕРПРЕТАЦИИ ОДНОЙ СТАРОЙ НАХОДКИ ${ }^{1}$
}

\author{
(С2021 г. Н.Ю. Смирнов
}

Статья посвящена уникальному предмету, который на протяжении последних 120 лет фигурирует в работах исследователей древностей ананьинской культурно-исторической области (общности) в качестве «культовой привески к поясу». Это резное изделие из рога, обнаруженное А.А. Спицыным в 1898 г. при раскопках погребения № 94 в могильнике у Зуевского починка на р. Каме (ГЭ, кол. 609, № 200). Предложенная и обоснованная в настоящей статье новая интерпретация этой вещи как рукояти кнута (конской плети) впервые логично и непротиворечиво объясняет ее функции и причины ее включения в число других предметов, сопровождающих погребенного. Наряду с этим, приводятся новые данные о перипетиях судьбы коллекции предметов из Зуевского могильника (и конкретно вещей из погребения № 94) с момента раскопок до передачи ее в фонды Государственного Эрмитажа и история первой сводной публикации этих материалов.

Ключевые слова: археология, А.А. Спицын, М.Г. Худяков, Зуевский могильник, погребение № 94, «культовая привеска», ананьинская культурно-историческая область (АКИО), кнут (конская плеть).

\section{ARTEFACT IN CULTURE: NEW EVALUATION OF AN OLD FIND ${ }^{2}$}

\section{N.Yu. Smirnov}

This paper examines a unique item which has been mentioned as a 'belt cult pendant' by researchers of the Ananyino culture in their studies over the past 120 years. It is a horn item discovered by Alexander A. Spitsyn in 1898 during the excavation of burial No. 94 at the burial ground near Zuyevskiy Pochinok on the Kama River. The new interpretation of this artefact as the grip of a horse whip proposed and substantiated in this article logically and consistently explains its function and why it was included in the other items accompanying the buried. At the same time, new information is provided concerning the fate of the collection of artefacts from Zuyevskiy burial ground (particularly the finds from burial No. 94) since excavations and until their transfer to the collections of the State Hermitage and first summarizing publication.

Keywords: archaeology, Alexander A. Spitsyn, Mikhail G. Khudyakov, Zuyevskiy burial ground, burial No. 94, 'cult pendant', Ananyino cultural and historical region (AKIO), horse whip.

«Хочешь что-нибудь спрятать? Положи на самое видное место».

Народная мудрость

\section{Предуведомление}

В основу настоящей статьи лег доклад, прочитанный автором 16 декабря 2005 г. на конференции, посвященной 75-летию Отдела археологии Восточной Европы и Сибири (ОАВЕС) Государственного Эрмитажа, в Санкт-Петербурге. Об изделии, назначе- ние которого реконструируется в настоящей статье, также шла речь в моем докладе 29 ноября 2016 г. на третьей Ананьинской конференции в Болгаре, на что уже появились отклики в печати (Черных, 2019а, с. 144).

Работа над этой статьей была начата в далеком уже 2005 году, когда хранительницей

1 Работа выполнена в рамках программы ФНИ ГАН РФ по теме государственного задания № 0184-20190004 «Взаимодействие древних культур Северной Евразии и цивилизаций Востока в эпоху палеометалла (IV тыс. до н. э. - І тыс. до н. э.)».

2 The work was carried out within the framework of the Fundamental Scientific Research Program of the Russian State Academy of Sciences on the topic of State Assignment No. 0184-2019-0004 "Interaction of Ancient Cultures of Northern Eurasia and Civilizations of the East in the Paleometal Period (4th Millennium BC - 1st Millennium BC)". 
коллекции предметов из Зуевского могильника в Государственном Эрмитаже была еще Елена Ивановна Оятева. Мы с Еленой Ивановной тогда долго и увлекательно спорили о назначении «костяной подвески» и ее заинтересованное и доброжелательное участие в моей работе, как и наши беседы, помнятся до сих пор. В день, когда я отправил текст статьи в журнал, пришло известие об уходе Елены Ивановны...

Светлой памяти двух выдающихся исследователей древностей Камско-Вятского региона, двух замечательных энтузиастов и подвижников науки - Елены Ивановны Оятевой и Александра Андреевича Спицына я и посвящаю свою статью.

Происхождение коллекции древностей из Зуевского могильника и начальный этап ее изучения

Предмет, которому посвящена настоящая статья, происходит из коллекции древностей, обнаруженных А.А. Спицыным в 1898 г. при раскопках могильника у Зуевского починка на р. Каме, напротив впадения в нее р. Белой. В значительном по размерам могильнике ананьинского времени было исследовано 218 погребений, большая часть из них оказалась непотревоженной и, зачастую, с обильным сопутствующим инвентарем. Всего коллекция предметов материальной культуры из раскопанных могил насчитывала 331 экземпляр (Древности Камы..., 1933, с. 6).

В том же году А.А. Спицыным было исследовано еще несколько памятников, материалы которых большей частью были изданы в течение следующих нескольких лет (Древности Камы..., с. 3). Зуевскому могильнику повезло меньше. В 1901 г. в Отчете Императорской археологической комиссии (далее ИАК) за 1898 г. были опубликованы краткие сведения о раскопках и приведен рисунок описываемой ниже вещи (Вятская губерния [Отчет], 1901, с. 43-46, рис. 70; Вятская губерния [Альбом], 1906, с. 290, № 1790). Известно, что А.А. Спицын подготовил сводные таблицы типичных находок (из Зуевского могильника и еще нескольких, изученных им, и ранее не публиковавшихся), однако дальше дело не пошло. Зуевская коллекция так никогда и не была издана первооткрывателем и исследователем этого замечательного памятника.

Буквально через два года после смерти А.А. Спицына, по решению Государственной академии истории материальной культуры (далее - ГАИМК), ее опубликовал М.Г. Худяков. Причины, по которым при жизни А.А. Спицына не состоялось издание находок из Зуевского могильника, М.Г. Худяков видел тогда в «определенном охлаждении (А.А. Спицына - Н.С.) к материалу», ссылаясь на сожаления самого автора раскопок о неверной культурной и хронологической интерпретации данной им «финским древностям» в предшествующих своих публикациях и сетуя на то, что «неоднократные обращения к А.А. Спицыну» со стороны коллег, с просьбами опубликовать эти материалы, ни к чему не привели (Древности Камы..., 1933, с. 4).

Но документы, сохранившиеся в Научном архиве Института истории материальной культуры РАН (далее - НА ИИМК РАН), зафиксировали иную версию событий. С самого начала привезенные А.А. Спицыным предметы хранились, вероятно, в фондах ИАК, а затем, уже в 1920-е гг., на Складе древностей ГАИМК в Мраморном дворце. В 1930 г. руководство ГАИМК приняло решение о ликвидации Склада, в связи с чем были назначены ответственные лица для передачи имевшихся коллекций в различные музеи. В том числе, со стороны ГАИМК - В.В. Гольмстен, а со стороны Эрмитажа, куда передавалась большая часть коллекций, - Э.К. Кверфельдт (Материалы..., 1931, л. 32-35). Находки из Зуевского могильника также должны были быть переданы в Эрмитаж. Вероятно зная о предстоящих пертурбациях, А.А. Спицын 19 сентября 1930 г. пишет записку (рис. 1) в комиссию по ликвидации Склада древностей ГАИМК: «Находил бы желательным сохранить до издания имеющиеся в складе вещии из моих раскопок в Вятской и Пермской губерниях. Таблицы для издания приготовлены, а само издание будет подготовлено в ближайшем будущем, после издания альбома золотых вещей с инкрустацией, которым я занят в настоящее время». Ниже приписка: «Для вещей найдется место в моем шкафу» (Материалы..., 1931, л. 10). Текст записки недвусмысленно свидетельствует о том, что исследователь и по прошествии трех десятков лет, полтора из которых были далеко не лучшими годами в жизни русских ученых, помнил о находках и более того желал их издать. Комиссия, однако, не сочла возможным временно оставить материалы А.А. Спицына в ГАИМК, хотя, в ряде других случаев, имеются рекомендации задержать или, даже, приостановить передачу коллекций в связи с необходимостью их обработки и публикации.

Уже 3 января 1931 г. вещи из Зуевского могильника, в составе других спицынских 


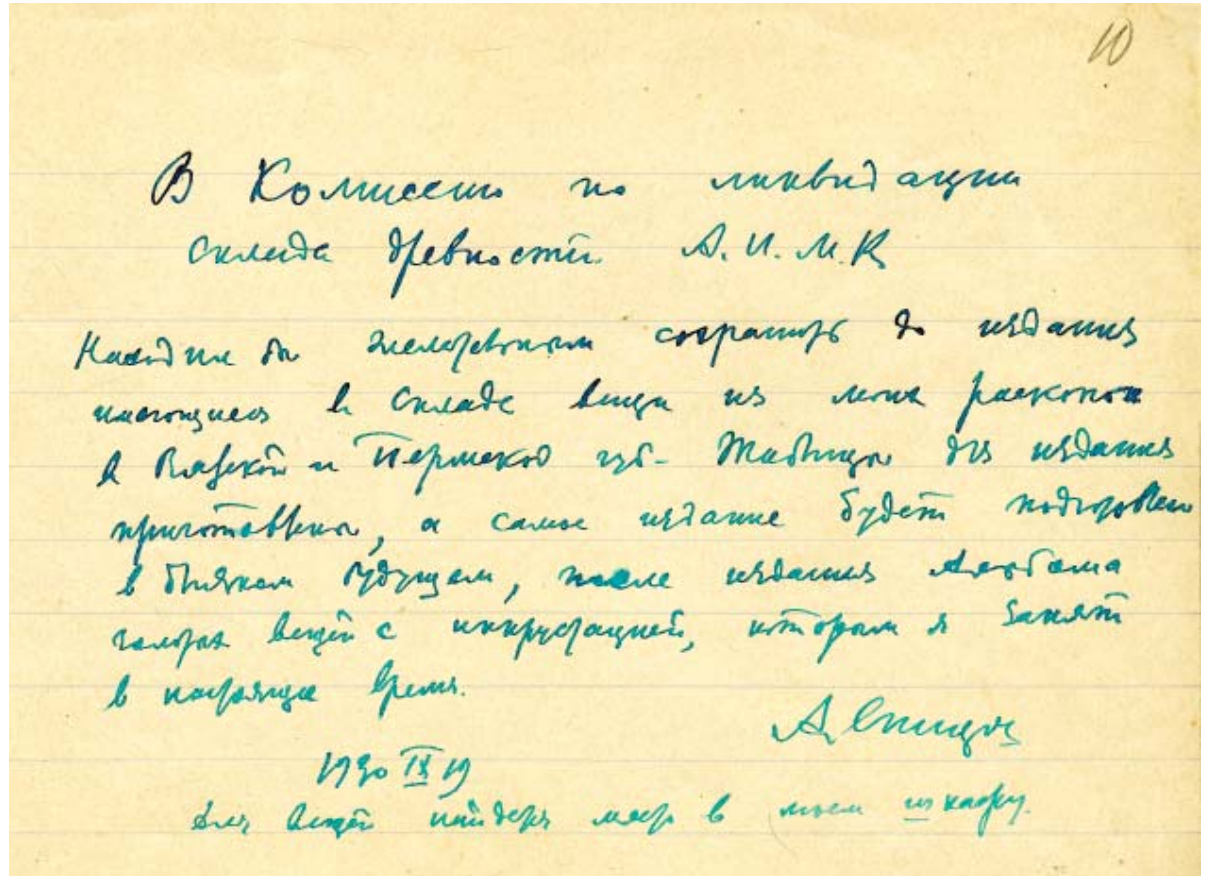

Рис. 1. Записка А.А. Спицына в комиссию по ликвидации Склада древностей ГАИМК.

Автограф. Чернила. Публикуется впервые (по: НА ИИМК РАН. РО, ф. 1, оп. 1, 1898 г., Д. 750, л. 10).

Fig. 1. A note by A.A. Spitsyn to the Commission for the Liquidation of the Warehouse of Antiquities of the State Academy for the History of Material Culture. Autograph. Ink. First publication (after: the Scientific Archive of the Institute for the History of Material Culture of the Russian Academy of Sciences. RO, f. 1, op. 1, 1898, d. 750, s. 10).

собраний, были переданы в Эрмитаж, где составили коллекцию под номером 609 (Материалы..., 1931, л. 32-35; ГЭ, кол. № 609). Этот же год стал последним в жизни исследователя Зуевского могильника - 17 сентября 1931 г. А.А. Спицын умер.

Всего через год М.Г. Худяковым были подготовлены и сданы в печать «Древности Камы по раскопкам А.А. Спицына в 1898 г.». В 1933 г. они вышли в свет в серии «Материалы ГАИМК» (Древности Камы..., 1933). Здесь следует сказать, что издатель пошел по наиболее простому пути - в книгу были помещены созданные еще А.А. Спицыным таблицы, без каких-либо дополнений, а также описания погребений и планы могильников, взятые из отчета о раскопках (Дело ИАК..., л. 19, 21, 51 и др.). Имевшиеся там же планы погребений с зарисовками сопроводительно- го инвентаря in situ были проигнорированы. Кроме этого публикация включала введение, посвященное работам А.А. Спицына в Прикамье, небольшой очерк изучения древностей Вятской губернии, а также разделы, характеризующие хозяйство и некоторые, особо интересные находки. Уделено было место и критическому анализу предшествовавших работ русских и финских археологов. Упомянутые части были написаны М.Г. Худяковым (Древности Камы..., 1933, с. 3-4, 5-10).

С тех пор исследователи еще несколько раз обращались к этому весьма интересному материалу, публикуя отдельные находки или рассматривая конкретные комплексы (Збруева, 1952, с. 40, 79, 139; Древнее искусство..., 1974, с. 175-176, рис. 67; Васильев, 2004, с. 279, рис. 20, 12; Черных, 2019а и др.), однако, в целом Зуевский могильник, как

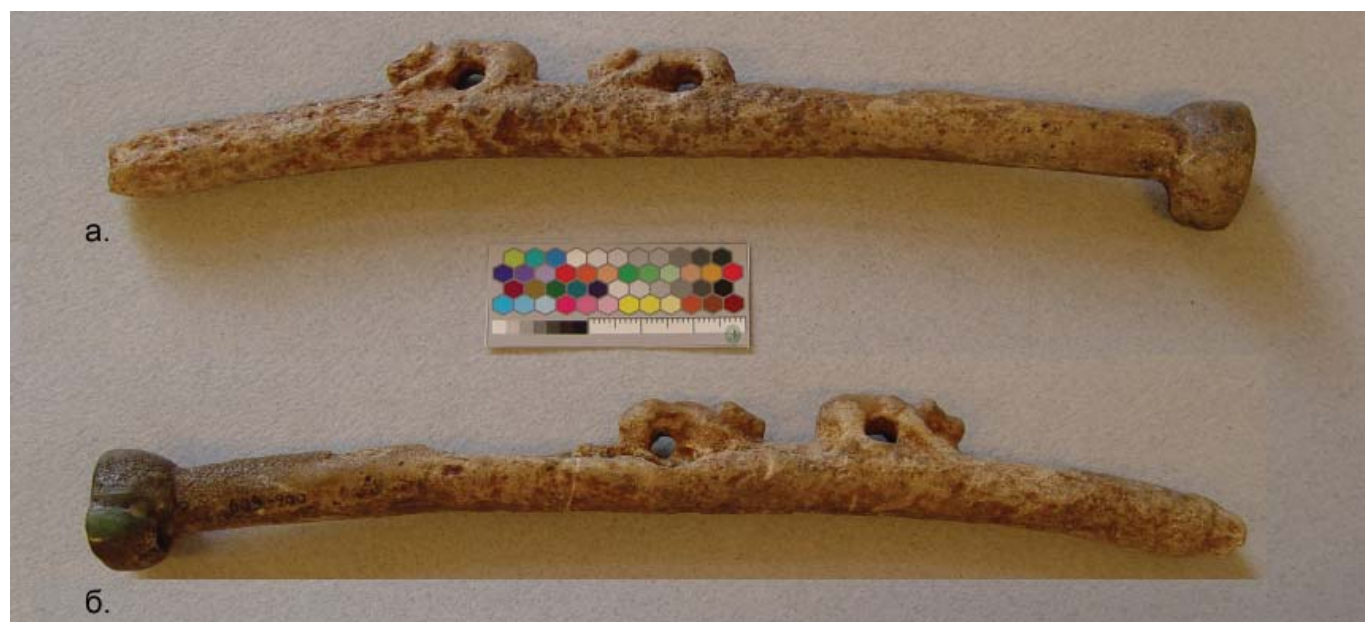

Рис. 2 а, б. Зуевский могильник, погребение № 94. Резная рукоять, рог. Фото автора. Fig. 2 a, б. Zuevsky burial ground, burial No. 94. Carved handle, horn. Photo by the author. 
и многие другие памятники АКИО, по справедливому замечанию С.В. Кузьминых все еще ждет достойного осмысления и публикации (Кузьминых, 2000, с. 108). В последние годы группой исследователей под руководством Е.M. Черных был предпринят ряд усилий для подготовки полной публикации материалов Зуевского могильника, однако эта важная работа все еще не доведена до конца (Черных, 2019б).

\section{Известная вешь неизвестного назначе-} ния

Тот, кто бывал на постоянной экспозиции древностей Восточной Европы, расположившейся с начала 1960-х гг. в Кутузовском коридоре Зимнего дворца, мог наблюдать в витрине под названием «Памятники ананьинской культуры» среди «изделий из кости» одну любопытную вещь (рис. 2: а, б). Это роговой предмет в виде слегка изогнутого стержня

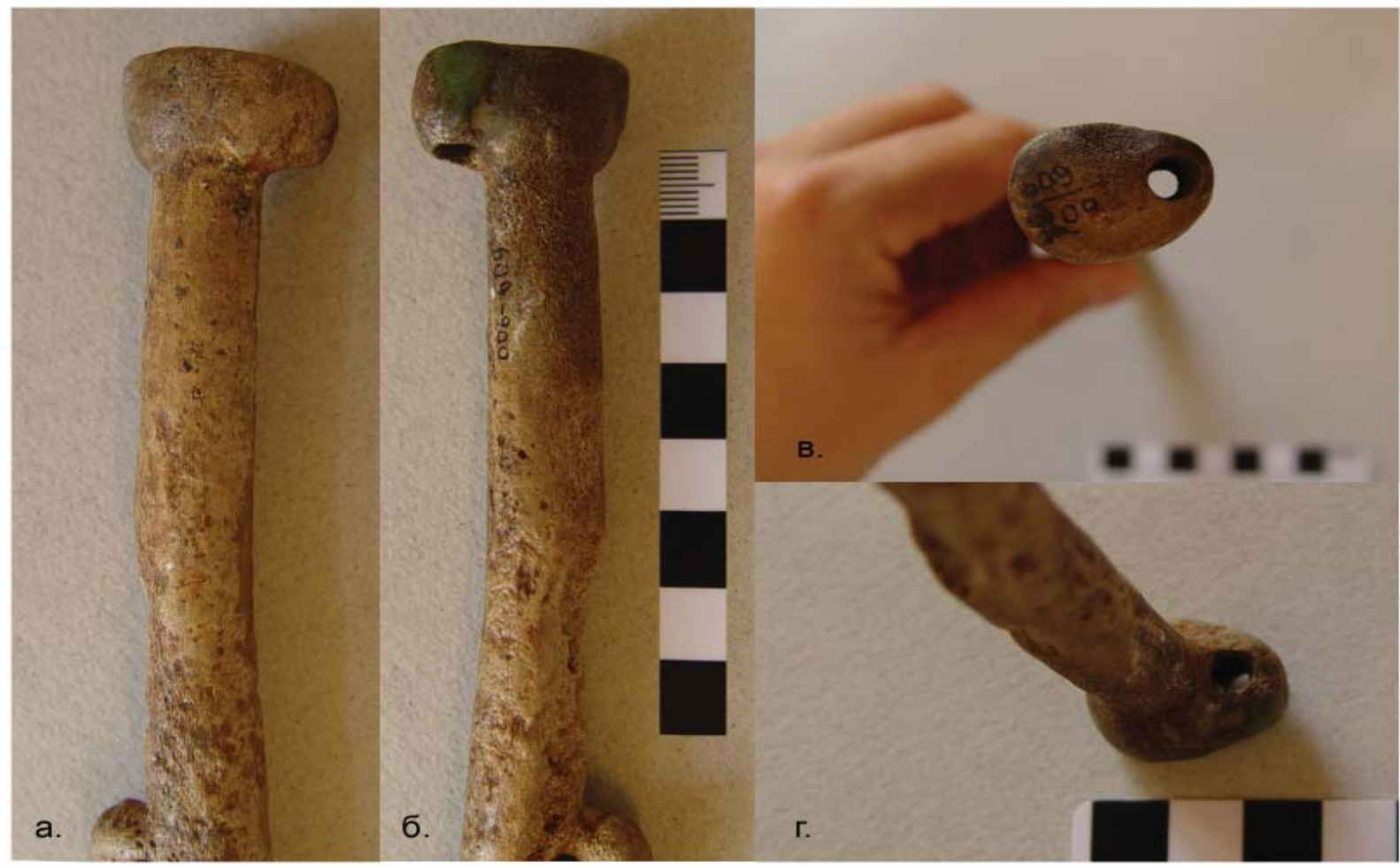

Рис. 3 а-г. Зуевский могильник, погребение № 94. Резная рукоять, рог. Фрагмент: окончание рукояти с затыльником. Фото автора.

Fig. 3 a-г. Zuevsky burial ground, burial No. 94. Carved handle, horn. Fragment: a handle tip with a back plate. Photo by the author.

диаметром 1,5 см и длинной сохранившейся части 22,2 см (ГЭ, кол. № 609, № 200). Внешний вид изделия свидетельствует о том, что оно было сломано в древности, возможно, преднамеренно, вследствие чего его длина уменьшилась.

На одном конце стержня имеется тщательно вырезанное завершение, по форме более всего напоминающее копыто животного, в котором просверлено параллельно стержню сквозное отверстие, расширяющееся к наружному краю завершения (рис. 3: а-г). Размеры завершения: 1,5×2,0×2,5 см. Диаметр просверленного отверстия: 0,5-0,6 см. С противоположной стороны изделие оканчивается сломом. Непосредственно перед местом слома имеются слабые следы контррельефной кольцевой выборки рога на глубину не более 0,1 см (рис. 2: б). На двух маленьких участ- ках с сохранившейся обработанной поверхностью ширина этой кольцевой выборки достигает 0,5-0,7 см.

Ближе к обломанному концу изделия, с выгнутой стороны стержня, расположены объемные изображения двух медведей, достаточно точно передающие видовые признаки животного (рис. 4: a-e). Четко смоделированы головы зверей с вытянутой мордой, с ее характерным переломом при переходе ко лбу, и округлыми ушами, рельефом показаны задние и передние конечности. У одной из фигурок можно различить короткий хвост (рис. 4: а-в, е). Обе фигурки имеют равную длину — три сантиметра, но передняя несколько крупнее - ее высота - 1,5 cм, а другой, меньшей, - 1 см. Между передними и задними лапами, под брюхом каждого животного имеются сквозные отверстия 

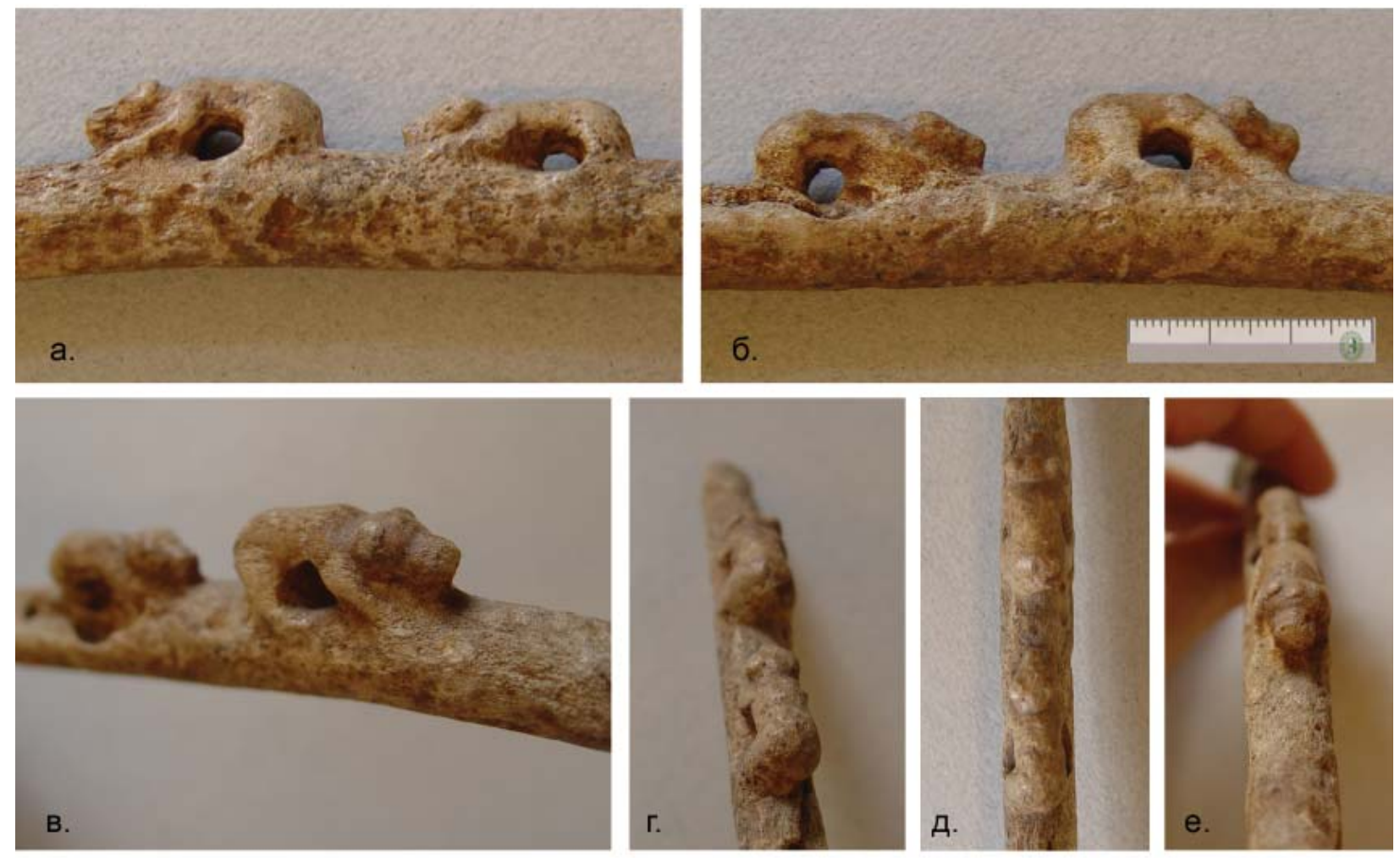

Рис. 4 а-е. Зуевский могильник, погребение № 94. Резная рукоять, рог. Фрагмент: резные фигурки медведей. Фото автора; в-е - без масштаба.

Fig. 4 a-e. Zuevsky burial ground, burial No. 94. Carved handle, horn.

Fragment: bear carvings. Photo by the author; B-e - not to scale.

круглой формы, диаметром 0,6 и 0,5 см соответственно. В этой части объемных изображений, при внимательном рассмотрении, можно заметить результаты применения техники контррельефа - углубленная полоса, шириной до 0,5 см охватывает туловище каждого животного с боков над отверстиями, исчезая на спине (рис. 4: а, г, д). Вероятно, это художественный прием, примененный для акцентирования бедер и плечевого пояса. Никаких следов трения с приложением усилия вокруг отверстий визуально не прослеживается. К сожалению, трасологические наблюдения сильно осложняются тем, что значительная часть обработанной поверхности рогового изделия деградировала в процессе археологизации. Есть места очень сильной выкрошенности пористой части рога, в том числе частично уничтожена малая фигурка медведя: с одного бока практически утрачены рельефные детали передней и задней лап. Более крупная фигурка медведя сохранилась гораздо лучше. Практически в идеальном состоянии сохранилась заполированная поверхность копытовидного завершения и примыкающая к нему часть стержня на длину 5 см (рис. 3: $\mathrm{a}-\Gamma)$.

Впервые рассматриваемый мной предмет был опубликован А.А. Спицыным в Отче- те ИАК за 1898 г. как «костяной стержень с фигурками медведей» (Вятская губерния [Отчет], 1901, с. 44, рис. 70); повторно изображение было приведено в (Вятская губерния [Альбом], 1906, с. 286, рис. 1790). Более качественный рисунок (по всей видимости, из таблиц, подготовленных еще А.А. Спицыным) был помещен М.Г. Худяковым в уже упоминавшемся издании (Древности Камы..., 1933, табл. 4 , рис. 8 , с. 12). В этой же работе впервые было дано подробное описание погребения № 94, включающее характеристику рогового предмета и изображение части вещей из комплекса. Сам А.А. Спицын еще в дневнике раскопок, исходя из места расположения предмета, назвал его «подвеской к поясу, в виде костяной палочки с изображением двух медведей». (Дело ИАК..., л. 46-47, 153). М.Г. Худяков в публикации 1933 г. отнес «подвеску» к «предметам с магическими изображениями» (Древности Камы..., 1933, с. 9).

Еще несколько раз комплекс погребения № 94 привлекал внимание исследователей в силу богатства инвентаря и хорошей сохранности. В монографии А.В. Збруевой были вновь опубликованы отдельные вещи оттуда, а в описании находок костяное изделие по традиции именовалось «привеской» (Збруева, 1952, с. 40, 79, 139). В альбоме «Древнее 
искусство...», изданном в 1974 г. большим коллективом авторов, оно также ,было названо «поясной подвеской» и связывалось с культом медведя. Основываясь на предметном составе сопроводительного инвентаря, авторы аннотации охарактеризовали погребенного как «военачальника или родового старейшину», а по присутствию в поясном наборе «культовой подвески» - как «служителя культа, жреца» (Древнее искусство..., 1974, с. 175-176, рис. 67). Ст.А. Васильев в работе, посвященной сложению ананьинского звериного стиля, относя среди немногих других вещей этот предмет к местной традиции (производство местных мастеров), поместил его в своем каталоге в отдел рукоятей, предполагая, что это рукоять ложки (Васильев, 2004, с. 279, рис. 20-12). Этим, пожалуй, и исчерпывается набор определений и характеристик.

Отмечу, что в каталоге выставки «Железный век. Европа без границ...», открывшейся в конце 2020 г. в Государственном Эрмитаже, как и в экспликации к предмету в витрине на временной экспозиции, эта вещь снова фигурирует просто как «костяная палочка» (Шаблавина, 2020).

\section{Контекст находки}

Необходимую информацию о контексте обнаружения этой необычной вещи можно почерпнуть из отчета А.А. Спицына (рис. 5 a, б). Описание дается мной по рукописному варианту отчета А.А. Спицына в ИАК (Дело ИАК..., л. 46 об.-47). При сверке текста рукописного отчета А.А. Спицына с текстом, опубликованным М.Г. Худяковым, оказалось, что они практически идентичны. Дополнения М.Г. Худякова, сделанные им для издания, помещены, как и в тексте публикации, в квадратные скобки.

«Мужсккой костяк, довольно хорошей сохранности. В изголовье большая глиняная чашка. Справа между плечом и черепом две золотыле изогнутые пластинки [представляющие собой половинки пластинчатого кольцуа с отверстиями для гвоздиков], у кисти правой руки медный кельт, восемь медных (с древками) и десять костяных наконечников стрел, все, как и кельт, остриями кногам, и железная кнопка с золотыли блестками [круглая бляха], на шее распавшаяся на пять частей витая медная шейная гривна, у кисти и частью у локтевой кости левой руки сильно изоржавевший железный наконечник копья. Вдоль левой руки протянут кожаный пояс [точнее два спускающихся вниз конца пояса], украшенный 48 медныли бляшками, снабженнылй двумя медными сужсиваюшчимися бляхами на коничах и медною застежкою (?) в виде палочки со сквозныл отверстием и кнопкою. У кониа пояса две привески: одна из них представляет плоский каменный оселок, прикреплявиийся к поясу с помошуью ремня (на который напущзены четыре медные пронизки) и медного приспособления [кольича] «в виде ключа», которое, быть может, висело на медной кнопке, помещзенной на ремне и примыкающей к застежке. Другая подвеска - костяная палочка с изображением двух медведей. Ширина ремня несколько более дюйма, а длина до 20 вериков (считая с застежкой). Близ второго конца две медные круглье пронизки, относящиеся, быть может, также к устройству пояса. Под копьем железный нож» (Дело ИАК..., л. 46 об.-47; Древности Камы..., 1933, с. 12).

Предметный комплекс погребения № 94 сохранился практически целиком - в процессе доставки в Петербург потерялись кельт и два или три «медных» наконечника стрел. В дневнике и отчете А.А. Спицына упоминаются восемь бронзовых наконечников стрел, а в справке ИАК об отсутствующих вещах (Дело ИАК..., л. 100б), возможно, составленной самим же А.А. Спицыным, наряду с кельтом указан и один «медный» наконечник стрелы. При этом на плане в дневниковой зарисовке (рис. 6) отмечено только пять «медных» наконечников стрел и в Эрмитаж их поступило пять экземпляров. Странно, что в случае с костяными наконечниками А.А. Спицын схематически зарисовал и указал в описи одинаковое число - 10 экземпляров (столько же поступило и в Эрмитаж), а в случае с «медными» вышла явная путаница.

Еще одно выявленное мной расхождение связано с полевым описанием и реальным состоянием шейной гривны. А.А. Спицын указывает на то, что она «распалась на пять частей», однако на гривне из этого погребения, хранящейся в Государственном Эрмитаже, видны следы спайки оловом в шести местах, что свидетельствует о том, что до реставрации фрагментов гривны было семь. На каком этапе произошла дополнительная фрагментация не ясно. О вероятных причинах подобного состоянии гривны в погребении ниже и в Приложении 1.

Большая часть вещей, происходящих из погребения № 94, хранится в настоящее время в фондах ОАВЕС. Некоторые наиболее интересные находки были представлены на старой, ныне разобранной, постоянной экспозиции в Кутузовском коридоре Зимнего дворца. 


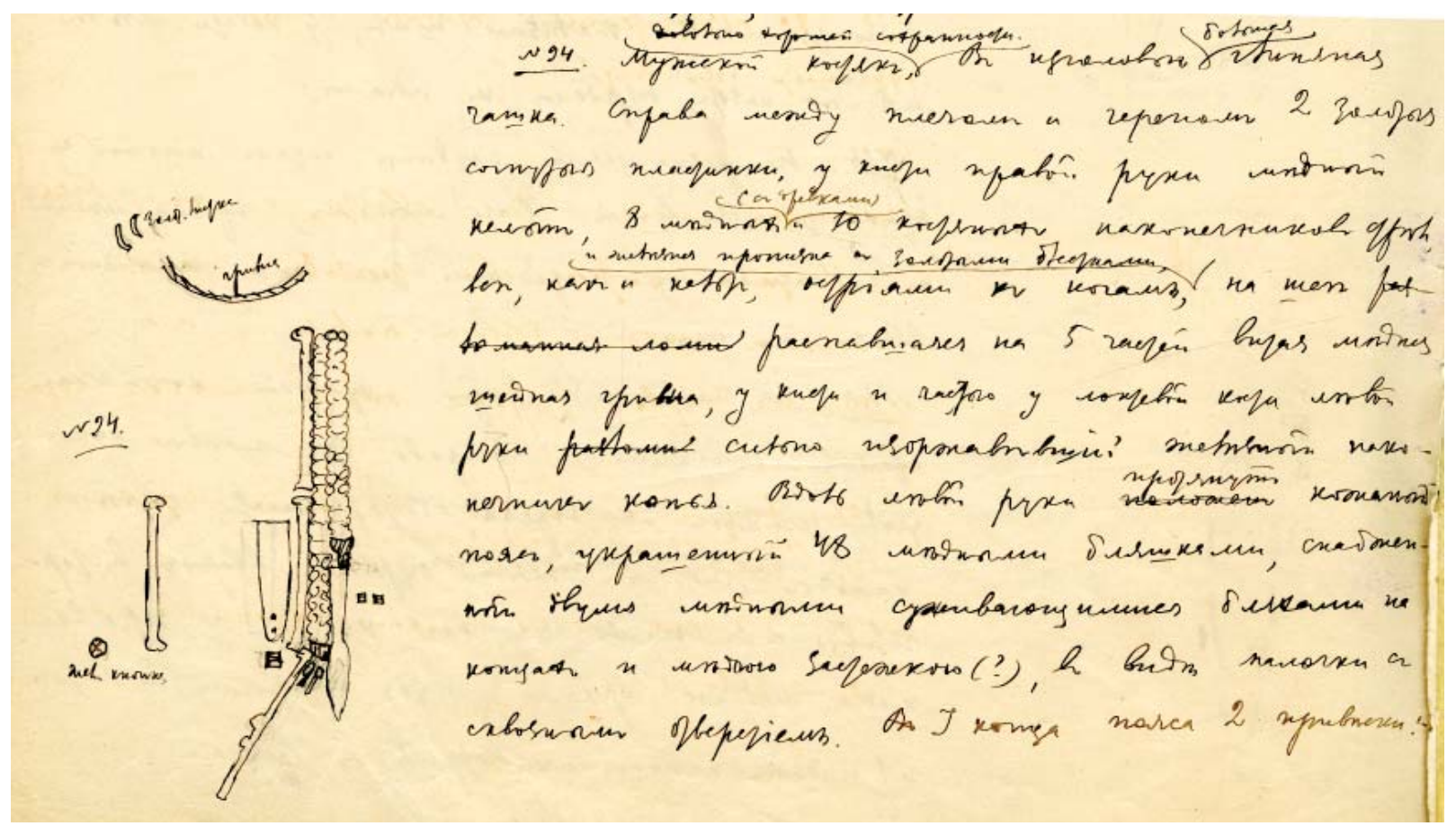

Рис. 5 а, б. Страницы из рукописного отчета А.А. Спицына в ИАК о раскопках Зуевского могильника. Схематический рисунок плана погребения № 94 и описание находок.

Автограф. Чернила.

Публикуется впервые (по: НА ИИМК РАН. РО, ф. 1, оп. 1, 1898 г., Д. 63, л. 46 об.-47).

Fig. 5 a, б. Pages from a handwritten report by A.A. Spitsyn to the Bulletin of Archaeological Commission concerning the excavations of Zuevsky burial ground. Schematic drawing of the plan of burial No. 94 and a description of the finds. Au-

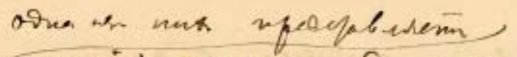

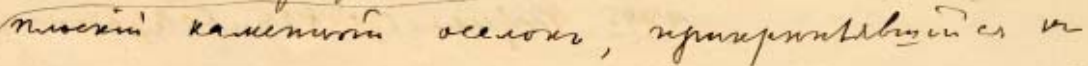

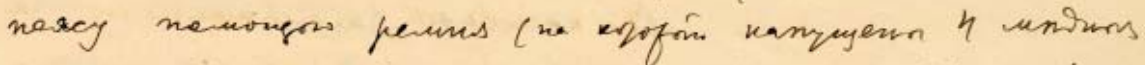

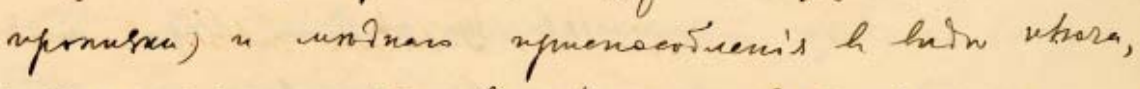

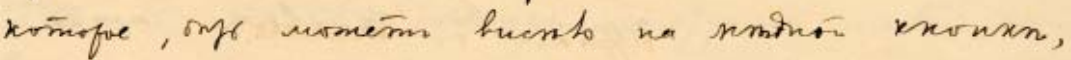

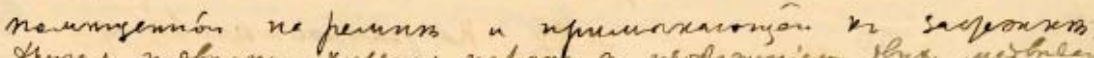

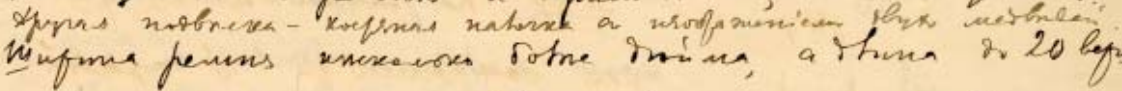

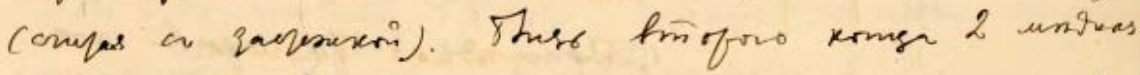

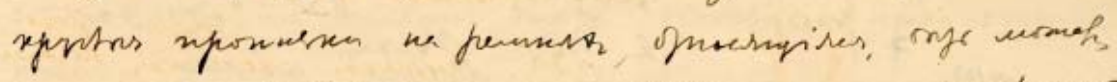

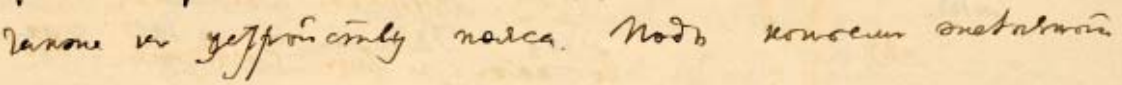

$$
\begin{aligned}
& \text { nomen. }
\end{aligned}
$$

tograph. Ink. First publication (after: the Scientific Archive of the Institute for the History of Material Culture of the

Russian Academy of Sciences. RO, f. 1, op. 1, 1898, d. 63, s. 46 rev.-47).

В полевом дневнике А.А. Спицына (Дело ИАК..., л. 153) имеется схематический чертеж погребения № 94 (рис. 6), а в рукописном отчете в ИАК (Дело ИАК..., л. 46 об.) - выкопировка из этого рисунка с более тщательной прорисовкой расположения вещей (рис. 5 a). В Эрмитаже, благодаря любезности хранителей коллекции Е.И. Оятевой и сменившей ее на этом посту Е.А. Шаблавиной, я смог осмотреть, сфотографировать и зарисовать практически все находки, за исключением золотых обкладок. По моей просьбе ряд изделий из цветных металлов был проанализирован C.B. Хавриным в Лаборатории научно-технической экспертизы Государственного Эрмитажа (Прил. 1).
Погребение № 94 Зуевского могильника не является уникальным для памятников АКИО и выделяется лишь сохранностью и набором предметов инвентаря (отдельные категории которого и их сочетания встречаются в погребениях этого и других могильников), а также присутствием известной «подвески». Поэтому на такие частности как место расположения пояса, место обнаружения исследуемой «подвески», оселка и состояние гривны и следует обратить особое внимание (рис. 5 а, 6).

Из схематической зарисовки А.А. Спицына видно, что пояс, длина которого в пересчете на современную систему измерения составляет почти 90 см, сложенный примерно попо- 


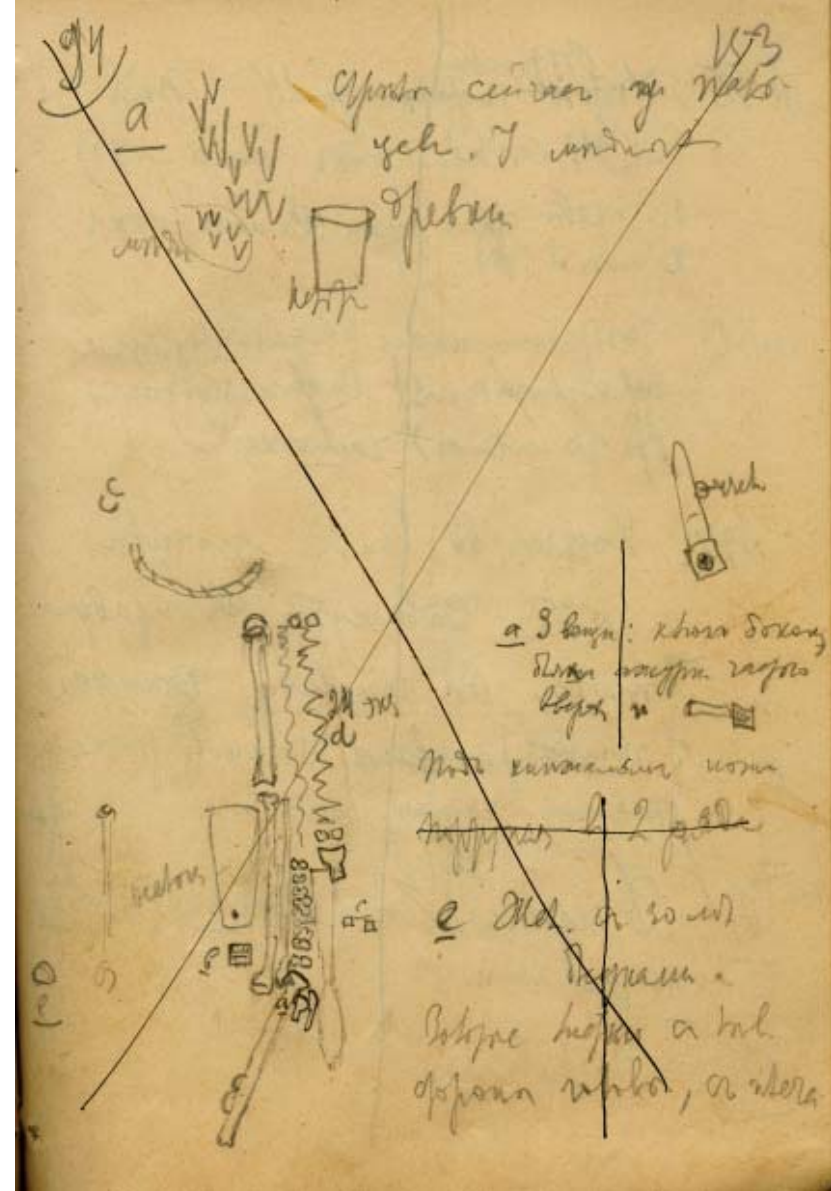

лам, был положен вдоль левой руки покойного, таким образом, что один из его концов находился на уровне кисти. Именно к этому концу, по описанию А.А. Спицына, крепились все три «привески». Расположение бронзовых «привесок» не вызывает вопросов - обе они подвешивались к поясу, вероятно, на кожаных шнурках. Роговая «привеска», теоретически, также могла крепиться к поясу с помощью петли из кожи или иных органических материалов. Ее расположение не противоречит такому предположению. Положение каменного оселка, подвешенного к поясу, свидетельствует о целенаправленном его размещении в области бедер покойного. Аналогию такому расположению знаковых предметов можно видеть в погребении № 168 этого же могильника, где у скелета погребенного мужчины в области тазовых костей и под(?) костями левого запястья была обнаружена, видимо, изначально подвешенная к поясу «крестовидная бляха» (Збруева, 1952, с. 40-41, табл. IV, 19; Древности Камы..., 1933, с. 13).

В настоящее время наличие знаковых категорий инвентаря и существование определенных закономерностей в их расположении в погребении признается большинством исследователей. Именно к такой категории относятся и оселки (Грязнов, 1961, с. 142). В нашем
Рис. 6. Страница из полевого дневника А.А. Спицына. Схематический рисунок плана погребения № 94 Зуевского могильника. Автограф. Карандаш, чернила. Публикуется впервые (по: НА ИИМК РАН. РО, ф. 1, оп. 1, 1898 г., д. 63, л. 153).

Fig. 6. A page from A.A. Spitsyn's field diary. Schematic drawing of the plan of burial No. 94 of Zuevsky burial ground. Autograph. Pencil, ink. First publication (after: the Scientific Archive of the Institute for the History of Material Culture of the Russian Academy of Sciences. RO, f. 1, op. 1, 1898, d. 63, s. 153).

случае дополнительным подтверждением этого может служить заключение М.Г. Жилина, проведшего, по моей просьбе, визуальный трасологический анализ, об отсутствии следов работы на оселке из погребения № 94.

Традиция размещения воинских поясов или перевязей с подвешенным к ним оружием не на теле погребенного, а рядом с ним, либо на стенке могилы или сруба над телом, или в специальных тайниках хорошо известна в захоронениях, которые относятся к скифскому культурно-временному кругу. Среди предметов, встречающихся в комплекте с поясами, фигурируют мечи, гориты и колчаны, а также нагайки или конские кнуты (Тереножкин, Мозолевский, 1988, рис. 45; Алексеев, Мурзин, Ролле, 1991, с. 61-62; Чугунов 2004, с. 19; Смирнов, 2015, с. 54).

Шейная гривна - еще одна знаковая деталь костюма покойного - была преднамеренно разломана на пять (или семь?) частей именно при погребении, а не распалась в процессе археологизации, как указал в отчете A.А. Спицын. Отмечу, что рукописный текст отчета несет на себе следы правки, имевшей место ещё в процессе написания. Интересно, что сначала А.А. Спицын описал гривну как «разломанную», а затем, зачеркнув это определение, изменил его на более нейтральное «распавшаяся» (Дело ИАК..., л. 46 об.).

Устное заключение о преднамеренной порче этого изделия сделали, по моей просьбе, научные сотрудники ОАВЕС Государственного Эрмитажа Р.С. Минасян и Е.А. Шаблавина. Их точку зрения подтвердили экспериментальные результаты, полученные С.В. Хавриным в Лаборатории научно-технической экспертизы Государственного Эрмитажа (Прил. 1). Порча предметов (в первую очередь оружия) в процессе совершения погребального обряда - хорошо известная традиция, фиксирующаяся как минимум с бронзового века. Спектр объяснений смысла этих действий достаточно широк, но в настоящем случае важно скорее то, что это еще одна вещь из погребения № 94, наряду с роговой «подвеской», ущербная, с 
точки зрения характеристик объекта материальной культуры. То, что она была именно сломана перед помещением в могилу, позволяет сделать допущение о таком же характере повреждения роговой «подвески» — eе преднамеренной порче.

Таким образом, можно заметить, что две статусные вещи погребенного - гривна и парадный воинский пояс, а также предметы, связанные с поясом (оселок и роговая «подвеска»), были специально деформированы или отъединены от тела покойного в процессе похорон.

\section{Опознание вещи}

Г. Чайлд как-то едко заметил, что появление категории «ритуальных» предметов в археологии древних обществ часто связано не с целенаправленным изучением материальных свидетельств духовной культуры, а с неспособностью исследователя определить реальное назначение вещей.

Совершенно в русле этой традиции, с момента своего обнаружения в конце XIX в. «костяная подвеска» с изображением двух медведей из Зуевского могильника считалась культовым, магическим атрибутом. Первое, рабочее описание, данное А.А. Спицыным в дневнике раскопок («подвеска к поясу»), было безоговорочно принято впоследствии всеми исследователями и публикаторами этой вещи, в качестве определения ее функции, что и обусловило непонимание ее назначения в последующие сто лет. На фоне значительного количества разнообразных поясных подвесок в погребениях АКИО еще одна, пусть и «культовая» как-то терялась...

Мое обращение к этой «подвеске» было достаточно случайным. В это время я занимался изучением одной категории погребального инвентаря центральноазиатских кочевников I тыс. до н. э., имеющей статусный характер. В поиске аналогий морфологическим характеристикам этих предметов, а также в процессе выявления основных принципов их использования в ритуальной сфере я целенаправленно искал эту категорию инвентаря в материалах кочевых и оседлых культур древности в достаточно широком хронологическом диапазоне и обширных географических рамках. В очередной раз, рассматривая витрины в Кутузовском коридоре, я опознал эту вещь, как относящуюся к той самой категории изделий, которая меня интересовала, и обратился к материалам Зуевского могильника, чтобы прояснить обстоятельства ее находки. Неожиданно оказалось, что назначение «подвески», очевидное для меня, как специалиста в области древностей кочевников, не было определено многочисленными публикаторами этой вещи, а ведь среди них были и исследователи АКИО, которым уже давно было ясно, что формирование предметного состава материальной культуры и появление некоторых художественных образов в искусстве АКИО происходило при сильном, если не доминирующем влиянии горностепных кочевых культур.

Сложившееся положение и заставило обратиться меня к более внимательному изучению самой вещи, ее контекста и обстоятельств находки.

К этому моменту озвученные предположения о назначении зуевской «подвески» сводились к тому, что она является рукоятью какого-то предмета. При этом, например, если Ст.А. Васильев в своей публикации относил ее под вопросом к ручкам ложек (Васильев, 2004), то хранитель коллекции (в 2005 г.) Е.И. Оятева, в разговоре со мной, уверенно отождествляла зуевскую «подвеску» с рукоятью «ритуальной ложки».

Действительно, и в этом я согласен с коллегами, эта вещь является рукоятью. Но, завершая процедуру более чем столетнего опознания, все же однозначно укажу сам предмет — это роговая рукоять кнута (конской плети). В.И. Даль приводит несколько терминов для обозначения разновидностей плети. В нашем случае, вероятно, наиболее точным будет использование термина «кнут» - «свитая из пеньки или ремешков и навязанная на кнутовище, короткая и к концу тонкая веревка для стеганья и битья» (Толковый словарь..., т. 2).

Постараюсь обосновать свою интерпретацию. Определение «подвеска» следует сразу же оставить, так как оно искажает сущность предмета и направляет интерпретатора по ложному пути. Это определение вторично по своей природе: «подвеской» может быть названа любая портативная вещь, прикрепленная с помощью ремешка или веревки к поясу, одежде, волосам и прочее.

Нет, оснований считать эту вещь и рукоятью ложки, в том числе «ритуальной», ничего похожего на костяные ложки в погребениях АКИО как будто нет. Большая часть резных костяных предметов ананьинского времени, определяемых как рукояти, является рукоятями ножей.

Кроме того, близкие по времени костяные ложечки, например, из погребений сарма- 
тов - кочевых обитателей соседнего мира степей — выглядят совершенно по-другому. Они имеют иные пропорции и размеры и, обычно, в неограбленных могилах сохраняются целиком. Хорошо известен облик таких ложечек, на которых орнаментация, если и присутствует, то лишь на конце рукояти, оформленном принципиально иначе, чем затыльник рукояти кнута из Зуевского могильника. Да и общие их размеры иные. В то же время, облик изделий степного кочевнического мира, уже достаточно давно и однозначно трактуемых как рукояти плетей, максимально приближен к зуевской рукояти (Бородовский, 1987; Дубовская, 1997; Шульга, 2005).

Приведу основные морфологические характеристики достоверных рукоятей плетей из археологических комплексов Евразии эпохи ранних кочевников.

Это деревянные, роговые или костяные, цельные или составные, стержневидные рукояти, нередко украшенные металлическими или роговыми накладками (кольцами, спиральной обмоткой), резьбой или раскрашенные, с набалдашниками/затыльниками (простыми и резными) и без них. Длина рукоятей в среднем составляет 25-30 см, а диаметр - 1,5-2 см.

Форма затыльника рукоятей кнутов складывается еще, видимо, в эпоху бронзы и мало меняется на протяжении эпохи ранних кочевников - это почти всегда некоторое утолщение (если это цельнорезная рукоять) или набалдашник (из кости или металла) копытовидного, грибовидного, редко, зооморфного облика. Ближайшую аналогию затыльнику зуевской рукояти можно видеть в окончаниях составных рукоятей (рукоятей с роговыми набалдашниками) из раннескифских погребений Северного Причерноморья, Приднепровья и Предкавказья (степной и лесостепной регионы) (Черненко, 1981, рис. 26 (Относительно ошибочности интерпретации Е.В. Черненко этих предметов в качестве деталей неясного назначения от горитов я уже кратко писал (Смирнов, 2015, с. 53-54)); Смирнов, 2015, рис. 1, 1). В качестве параллелей элементам оформления зуевской рукояти также можно привести набалдашники и затыльники рукоятей кнутов из сакских погребений первой половины и середины I тыс. до н. э. в Средней Азии и погребений эпохи ранних кочевников на Алтае (Шульга, 2005, рис. 1, 1, 2, 11-14).

Маленькое отверстие в затыльнике или дополнительное отверстие в съемном набалдашнике, расположенное параллельно руко- яти, служит для пропуска ремешка или тесемки, образующих петлю, - темляка, с помощью которого можно подвешивать плеть к поясу или фиксировать на запястье руки всадника в процессе управления конем (см., например, наличие темляка у цельнодеревянной рукояти: Шульга, 2015, рис. 86, 3, 4).

Костяные или роговые рукояти кнутов или их детали известны в погребениях скотоводов-кочевников, начиная еще с эпохи бронзы (Отрощенко, 1986). Цельные роговые рукояти найдены как в предскифских и раннескифских памятниках Восточной Европы (Дубовская, 1997), так и в памятниках синхронного периода в Средней Азии и Сибири (Шульга, 2005, рис. $1,1,8,10)$.

Некоторые дополнительные данные можно почерпнуть из анализа иконографии киммерийских и скифских изваяний. На ряде изваяний присутствуют характерные атрибуты всадника-кочевника, однозначно опознаваемые как кнуты/нагайки. В этих случаях кнуты показаны подвешенными к поясу, с левой стороны фигуры воина, или зажатыми в правой руке изображенного персонажа (Ольховский, Евдокимов, 1994, рис. 48, 81; 77, 128). Иногда кнут передавался только барельефным изображением рукояти (нередко с хорошо читаемым набалдашником грибовидной или округлой формы и наконечником, имеющим выраженную клювовидную форму). В ряде случаев показывалась и ременная часть кнута.

Присутствие кнутов (рукоятей или их деталей) в составе поясных наборов, включающих, кроме самого пояса или перевязи, предметы вооружения (меч, кинжал, горит с колчаном, чекан и проч.), помещенных в стороне от тела умершего, часто слева, на уровне плеча, бедер или ног, неоднократно зафиксировано при исследованиях погребений скифского культурно-временного круга (Смирнов, 2015 , c. 54).

Приведенные выше морфологические характеристики и особенности расположения предмета в погребении недвусмысленно свидетельствуют в пользу предложенной мной интерпретации зуевской «подвески» в качестве роговой рукояти кнута (конской плети).

\section{Реконструкция предмета}

Для завершения реконструкции облика кнута (конской плети) из погребения № 94 Зуевского могильника остается ответить на несколько вопросов.

Во-первых, желательно понять, была ли роговая рукоять сломана в процессе выполне- 


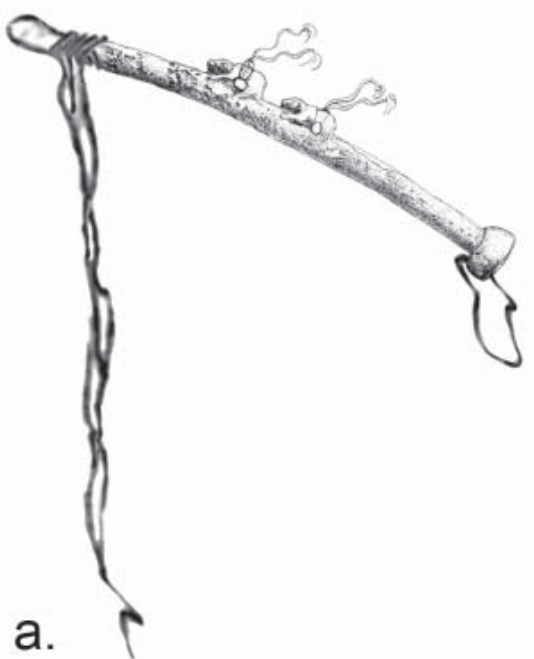

б.

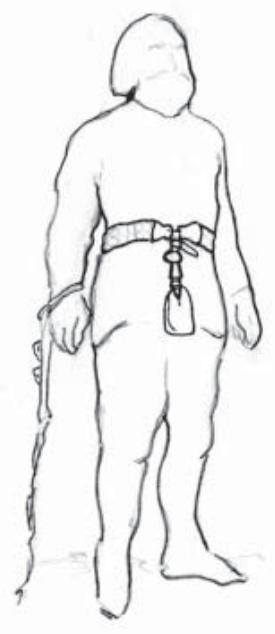

Рис. 7, а, б. Реконструкция внешнего вида кнута (конской плети) из погребения № 94 Зуевского могильника и возможного способа удержания кнута, при накидывании темляка на запястье воина. Рисунок-реконструкция Н.Ю. Смирнова и Д.К. Помазановой. Fig. 7 а, б. Reconstruction of the appearance of a whip (horse lash) from burial No. 94 of Zuevsky burial ground and the possible means of holding the whip, whereby a lanyard is wrapped over a warrior's wrist. A reconstruction drawing by N.Yu. Smirnov and D.K. Pomazanova.

ния обрядовых действий в момент совершения погребения или же она была обломана в процессе использования кнута?

Можно предположить, опираясь на размерные характеристики сравнительного материала, что отломана была примерно 1/5-1/6 часть рукояти, возможно, имевшая фигурное завершение для крепления ременной части кнута. Последнее, однако, доказать невозможно. Повреждение рукояти в процессе использования кнута представляется менее вероятным, учитывая то, что место ее излома расположено ближе к концу, к которому крепилась ременная часть.

Предпочтительным будет являться вывод о том, что деформация рукояти кнута носила ритуальный характер. На это указывает контекст и характер находки: могила, погребальный инвентарь. Дополнительным аргументом может служить состояние еще одного знакового предмета - шейной гривны, которая была разломана на множество фрагментов при помещении в могилу. Не исключено, что отломанная часть рукояти, вместе с кожаной частью кнута, при этом была сознательно изъята (не помещена в могилу). Иначе А.А Спицын обнаружил бы ее при раскопках.

Во-вторых, желательно выяснить, было ли что-то прикреплено к фигуркам медведей, расположенным в средней части рукояти. Визуальный осмотр не позволяет утвердительно ответить на этот вопрос, но и не дает информации для отрицательного ответа. Вероятно, необходимо провести трасологический анализ внутренней поверхности отверстий под фигурками медведей. До этого любые предположения будут иметь спорный характер. Хотя, как я уже писал выше, подобный анализ будет осложнен плохим состоянием материала (сильная выкрошенность поверхностных слоев рогового изделия).
И все же выдвину предположение, кажущееся мне близким к истине - к фигуркам медведей были привязаны какие-то легкие декоративные элементы типа тканых лент или плетеных шнуров. Иначе трудно объяснить необходимость просверливания отверстий под фигурками животных - для создания объемного изображения - это излишние действия. В то же время, очевидно, что расположение отверстий препятствует приложению к этой части рукояти серьезной нагрузки это неминуемо привело бы к расщеплению роговой основы.

В реконструированном виде кнут из погребения № 94 Зуевского могильника мог бы выглядеть так, как изображено на рис. 7: а, б. В этом случае получают объяснения все особенности морфологии странной «костяной подвески», которая в реальности является роговой рукоятью кнута (конской плети). Опытным путем установлено, что стандартный способ удержания рукояти в руке при работе кнутом (конской плетью) вполне соответствует размерным и морфологическим характеристикам изделия (рис. 8).

Вещь в культуре или культурные роли кнута (конской плети)

Появление в материальном комплексе АКИО, в контексте погребения, такой знаковой вещи степного мира кочевников как кнут (конская плеть), конечно, вызывает целый ряд вопросов. Присутствие кнутов среди сопроводительного инвентаря в могилах самих кочевников не так уж часто фиксируется, что, возможно, связано с традицией их изготовления из легко истлевающих органических материалов (дерево, кожа), статусным характером этой категории инвентаря, а также рядом других факторов (Шульга, 2005, с. 183).

В материальной культуре АКИО кнуты (конские плети) или их детали фиксируют- 


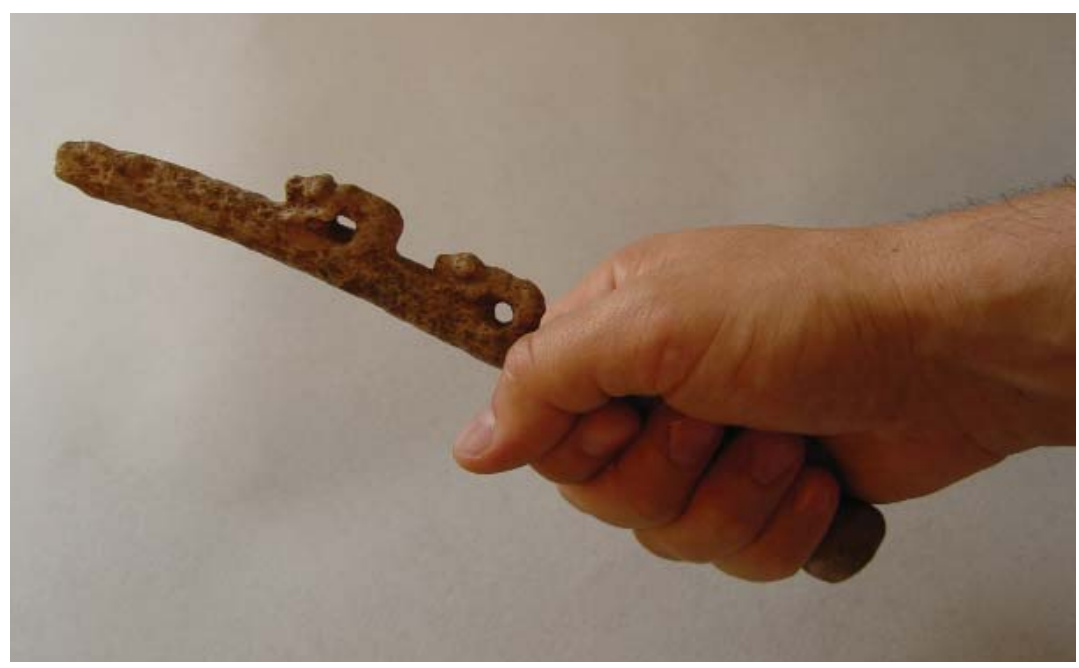

Рис. 8. Демонстрация способа захвата предмета рукой при использовании его в качестве рукояти кнута (конской плети). Фото автора.

Fig. 8. Demonstration of the means of gripping an item with a hand when using it as a whip handle (horse lash).

Photo by the author.

ся вообще чрезвычайно редко, и до сих пор нет сводной работы по этой категории изделий. Впервые наличие среди материального комплекса АКИО деталей кнутов предположила О.Р. Дубовская, не без оснований отнеся к этой категории некоторые бронзовые навершия, происходящие из погребений (Дубовская, 1997, рис. 1, 8, 9). В 2016 г., на третьей Ананьинской конференции в Болгаре, я сделал доклад, в котором обобщил данные о навершиях из погребальных памятников АКИО (Старший Ахмыловский, Акозинский и Пустоморквашинский могильники), которые мне удалось лично осмотреть и зарисовать, а также определить их функциональное назначение в качестве деталей рукоятей кнутов. Вместе с кнутовищем из Зуевского могильника на настоящий момент мне удалось отождествить детали кнутов не более чем в десяти случаях. Тем интереснее на этом фоне выглядит цельнорезная зуевская рукоять.

Несомненно, что перед нами не рядовая (бытовая) вещь, а статусное изделие, на что указывает материал (рог), тщательность обработки и наличие декора в местном зверином стиле. Учитывая богатые традиции коневодства и скотоводства у представителей АКИО (Петренко, 2007, с. 67-73), их знакомство с кнутами и плетями, как и использование этих орудий управления верховой лошадью и скотом в хозяйстве, не вызывает сомнений. Однако помещение их в могилы, особенно в составе парадного воинского поясного набора, следует рассматривать в контексте влияний культурных традиций их соседей кочевников-скотоводов горностепного мира. Эти влияния, очень заметные в сфере вооружения, конского снаряжения и декора (скиф- ский звериный стиль) АКИО, в настоящий момент являются общепризнанными. Морфология других изделий из погребений АКИО, опознаваемых мной в качестве деталей рукоятей кнутов, не противоречит этому выводу в массе своей это вещи, сделанные из бронзы, и несущие на себе черты аналогичных изделий степного мира или стилистически близкие кругу изделий, связанных с колесничной упряжью, Северного Кавказа (разнообразные прорезные и зооморфные фигурные металлические навершия).

В жизни скотоводов-кочевников кнут (конская плеть) играет целый спектр культурных ролей: орудие управления лошадью, охотничье оружие, индикатор социального статуса владельца, ритуальное оружие (Бородовский, 1987; Дубовская, 1997; Шульга, 2005; Смирнов, 2014; Smirnov, 2020). Многое о статусе и назначении самой вещи могут сказать особенности ее декора, материал, из которого она изготовлена, и контекст обнаружения.

В среде представителей АКИО, скорее всего, происходит редукция части культурных ролей кнута (конской плети) по сравнению со степным миром. Однако основные роли орудие управления лошадью, маркирование социального статуса - остаются неизменными, что подтверждается закономерностью в обнаружении деталей кнутов в погребениях с элементами конской узды, оружием или парадным поясным набором воина. Я предполагаю, что кнут (конская плеть) в среде представителей АКИО сохраняет и свою ритуальную роль, но объективных данных для категорического утверждения этого в настоящий момент недостаточно. 


\section{ЛИТЕРАТУРА}

Алексеев А.Ю., Мурзин В.Ю., Ролле Р. Чертомлык. Скифский царский курган IV в. до н.э. К.: Наукова думка, $1991.411 \mathrm{c.}$

Бородовский А.П. Плети и возможности их использования в системе вооружения племен скифского времени // Военное дело древнего населения Северной Азии / Отв. ред. В.Е. Медведев, Ю.С. Худяков. Новосибирск: Наука, 1987. С. 28-39.

Васильев Cm.A. Ананьинский звериный стиль. Истоки, основные компоненты и развитие // Археологические вести. 2004. № 11. С. 275-297.

Вятская губерния // Альбом рисунков, помещенных в отчетах ИАК за 1882-1898 гг. СПб.: Тип. Главного управления уделов, 1906. С. 281-288.

Вятская губерния // Отчет ИАК за 1898 г. СПб.: Тип. Главного управления уделов, 1901. С. 41-46.

Грязнов М.П. Так называемые оселки скифо-сарматского времени // Исследования по археологии СССР. Сборник статей в честь М.И. Артамонова / Отв. ред. В.Ф. Гайдукевич. Л.: Изд-во ЛГУ, 1961. C. $139-144$.

Дело ИАК об археологических изысканиях члена Комиссии А.А. Спицына в губерниях: Вятской, Уфимской, Казанской, Пермской / НА ИИМК РАН. РО, ф. 1, оп. 1, 1898 г., д. 63.

Древнее искусство. Памятники палеолита, неолита, бронзового и железного веков на территории Советского Союза. Собрание Государственного Эрмитажа / Отв. ред. М.И. Артамонов. Л.: Аврора, 1974. $196 \mathrm{c}$.

Древности Камы по раскопкам А.А. Спицына в 1898 г. // Материалы ГАИМК. Вып. 2. / Отв. ред. С.Н. Быковский / Л.: Типография «Печатный Двор», 1933. 38 с.

Дубовская О.Р. Плеть как возможный атрибут предскифских погребений // Памятники предскифского и скифского времени на юге Восточной Европы / МИАР. № 1 / Отв. ред. Р.М. Мунчаев, В.С. Ольховский. М.: ИА РАН, 1997. С. 57-61.

Збруева А.В. История населения Прикамья в ананьинскую эпоху / Материалы и исследования по археологии Урала и Приуралья. Т. V / МИА. № 30. М.: Изд-во АН СССР, 1952. 326 с.

Кузьминых С.В. Археологическое изучение ананьинского мира в XX веке: основные достижения и проблемы // Российская археология: достижения XX и перспективы XXI вв. Матер. науч. конф. к 75-летию В.А. Генинга. Ижевск: Издательский дом «Удмуртский университет», 2000. С. 104-113.

Материалы, связанные с комиссией по ликвидации Склада древностей ГАИМК / НА ИИМК РАН. PО, ф. 2, оп. 1, 1931 г., д. 750.

Ольховский В.С., Евдокимов Г.Л. Скифские изваяния VII-III вв. до н. э. М.: ИА РАН, 1994. 188 с.

Отрощенко В.В. Костяные детали плеток из погребений срубной культуры // СА. 1986. № 3 С. $72-81$.

Петренко А.Г. Становление и развитие основ животноводческой деятельности в истории народов Среднего Поволжья и Приуралья (по археозоологическим материалам) / Археология евразийских степей. Вып. 3. Казань: Ин-т истории АН РТ, 2007. 144 с.

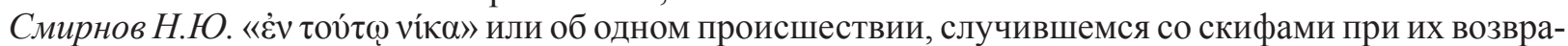
щении из Азии (Herod., IV. 1. 3, 3, 4) // Доісламський Близький Схід: історія, релігія, культура / Отв. ред. М.О. Тарасенко. Київ: Інститут сходознавства ім. А.Ю. Кримського НАН України, 2014. С. 235-240.

Смирнов Н.Ю. Зверь и птица из Темир-Горы // Боспорские исследования Вып. XXXI. / Отв. ред. В. Н. Зинько. Керчь: Керченская городская типография, 2015. С 50-59.

Тереножкин А.И., Мозолевский Б.Н. Мелитопольский курган. Киев: Наукова думка, 1988. 264 с.

Толковый словарь живого великорусского языка В.И. Даля. Т. 2: И-О. СПб.-М.: Тип. М.О. Вольфа, 1881.

Черненко Е.В. Скифские лучники. Киев: Наукова думка, 1981. 167 с.

Черных E.M. Предметы конского снаряжения из Зуевского могильника ананьинской культуры шнуровой керамики в Удмуртии // Поволжская археология. 2019а. № 1(27). С. 136-149.

Черных E.M., К 120-летию начала исследований Зуевского (Зуевоключевского I) могильника // Археология Евразийских степей. 2019б. № 2. С. 227-245

Чугунов K.B. Аржан - источник // Аржан. Источник в долине царей. Археологические открытия в Туве / Отв. ред. М.Б. Пиотровский. СПб.: Славия, 2004. С. 10-37.

Шаблавина Е.А. Древности раннего железного века на территории Прикамского Приуралья в собрании Государственного Эрмитажа // Железный век. Европа без границ. Первое тысячелетие до н. э.: каталог выставки / Отв. ред. А.Ю. Алексеев, М. Наврот, А. Гасс, Ю.Ю. Пиотровский. СПб.: Чистый лист, 2020. С. 256-269.

Шульга П.И. О находках нагаек скифского времени на Алтае // Снаряжение кочевников Евразии / Отв. ред. А.А. Тишкин. Барнаул: Изд-во АлтГУ, 2005. С. 183-189.

Шульга П.И. Снаряжение верховой лошади в Горном Алтае и Верхнем Приобье. Ч. II (VI-III вв. до н.э.). Новосибирск: РИЦ НГУ, 2015б. 322 с. 
Smirnov N.Yu. In hoc signo vinces: the victory of the Scythians over the offspring of their slaves as a manifestation of divine providence (Herodotus, The Histories 4.1 [3], 3, 4) // Masters of the Steppe: The Impact of the Scythians and Later Nomad Societies of Eurasia Proceedings of a conference held at the British Museum, 27-29 October 2017. / S. Pankova, St. John Simpson (eds.). London: Archaeopress Publ., 2020. P. 544-550. Информация об авторе:

Смирнов Николай Юрьевич, кандидат исторических наук, старший научный сотрудник, Институт истории материальной культуры РАН (г. Санкт-Петербург, Россия); kolaksais@yandex.ru

\section{REFERENCES}

Alekseev, A. Yu., Murzin, V. Yu., Rolle R. 1991. Chertomlyk. Skifskii tsarskii kurgan IV v. do n.e. (Chertomlyk. Scythian Tsar's Barrow of the 4th century BC.). Kiev: "Naukova dumka" Publ. (in Russian).

Borodovsky, A. P. 1987. In Medvedev, V. E., Khudyakov, Yu. S. (eds.). Voennoe delo drevnego naseleniya Severnoy Azii (Military Arts of the Ancient Population of Northern Asia). Novosibirsk: "Nauka" Publ. 28-39 (in Russian).

Vasilev, St. A. 2004. In Arkheologicheskie vesti (Archaeological News) 11. 275-297 (in Russian).

Vyatskaia guberniia (Vyatka Governorate). 1906. In Al'bom risunkov, pomeshhennykh v otchetah IAK za 1882-1898 gg. (Album of Drawings Included in the Reports of the Bulletin of Archaeological Commission for 1882-1898.), 281-288 (in Russian).

Vyatskaia guberniia (Vyatka Governorate). 1901. In Otchet Arkheologicheskoi komissii za 1898 g. (Report of the Imperial Archaeological Commission from 1898), 41-46 (in Russian).

Gryaznov, M. P. 1961. In Gaidukevich, V. F. (ed.). Issledovaniia po arkheologii SSSR. Sbornik statei v chest' M.I. Artamonova (Studies on the Archaeology of the USSR. Collection of Papers Dedicated to M.I. Artamonov). Leningrad: Leningrad State University, 139-144 (in Russian).

1898. Delo Imperatorskoi arkheologicheskoi komissii ob arkheologicheskikh izyskaniiakh clean Komissii A.A. Spitsyna v guberniiakh: Vyatskoi, Ufimskoi, Kazanskoi, Permskoi (Case of the Imperial Archaeological Commission on the Archaeological Studies by Member of the Commission A.A. Spitsyn in Vyatka, Ufa, Kazan, Perm Governorates). Scientific Archive of the Institute for the History of Material Culture, Russian Academy of Sciences. Fund 1, dossier 63 (in Russian).

In Artamonov, M. I. (ed.). 1974. Drevnee iskusstvo. Pamiatniki paleolita, neolita, bronzovogo i zheleznogo vekov na territorii Sovetskogo Soiuza.sobranie Gosudarstvennogo Ermitazha (Ancient Art. Monuments of the Paleolithic, Neolithic, Bronze and Iron Ages in the Territory of the Soviet Union. Collection of the State Hermitage). Leningrad: "Avrora" Publ. (in Russian).

Bykovsky, S. N. 1933. (ed.). In Drevnosti Kamy po raskopkam A. A. Spitsyna v 1898 g. (Antiquities of the Kama Area on the A. A. Spitsyn's Excavations in 1898). Series: Proceedings of the State Academy for the History of Material Culture 2. Leningrad: "Pechatnyi Dvor" Typography (in Russian).

Dubovskaya, O. P. 1997. In Munchaev, R. M., Olkhovsky, V. S. (eds.). Pamiatniki predskifskogo i skifskogo vremeni na iuge Vostochnoi Evropy (Monuments of the Pre-Scythian and Scythian Periods in the Southern Part of Eastern Europe). Materialy i issledovaniia po arkheologii Rossii (Materials and Research of Russian Archaeology) 1. Moscow: Institute of Archaeology, Russian Academy of Sciences, 57-61 (in Russian).

Zbrueva, A. V. 1952. Istoriia naseleniia Prikam 'ia v anan'inskuiu epokhu (History of the Population of the Kama River Region in the Ananyino Time). Series: Materialy i issledovaniia po arkheologii Urala i Priural'ia (Materials and Research on the Archaeology of Ural and the Cis-Urals Area) V. Materialy i issledovaniia po arkheologii SSSR (Materials and Research in the USSR Archaeology) 30. Moscow: Academy of Sciences of the USSR (in Russian).

Kuzminykh, S. V. 2000. Rossiiskaia arkheologiia: dostizheniia XX i perspektivy XXI vv. (Russian Archaeology: Achievements of $20^{\text {th }}$ and Prospects for $21^{\text {st }}$ Centuries). Izhevsk: "Udmurtskii universitet" Publ., 104-113 (in Russian).

1931. Materialy, sviazannye s komissiei po likvidatsii Sklada drevnostei Gosudarstvennoi akademii istorii materialmoi kul 'tury (Materials Related to the Commission for the Liquidation of the Warehouse of Antiquities of the State Academy for the History of Material Culture). Scientific Archive of the Institute for the History of Material Culture, Russian Academy of Sciences. RO. Found 2. Doisser 750 (in Russian).

Ol'khovsky, V. S., Evdokimov, G. L. 1994. Skifskie izvaianiia VII-III vv. do n.e. (Scythian Statues of the 7th-3rd Centuries BC.). Moscow: Institute of Archaeology RAS (in Russian).

Otroshchenko, V. V. 1986. In Sovetskaya arkheologiya (Soviet archeology). (3). $72-81$ (in Russian).

Petrenko, A. G. 2007. Stanovlenie i razvitie osnov zhivotnovodcheskoi deiatel'nosti v istorii Srednego Povolzh 'ia i Priural'ia (po arkheozoologicheskim materialam) (Establishment and development of the foundations of cattle breeding in the history of peoples from the Middle Volga region and Pre-Urals (on the basis of archaeological materials). Series: Arkheologiia Evraziiskikh stepei (Archaeology of the Eurasian Steppes) 3. Kazan: Institute of History, Academy of Sciences of the Republic of Tatarstan (in Russian) 
Smirnov, N. Yu. 2014. In Tarasenko, M. O. (ed.). Doislams'kii Bliz'kii Ckhid: isroriia, religiia, kul'tura (Pre-Islamic Near East: History, Religion, Culture). Kiev: A. Krymskyi Istitute of Oriental Studies, National Academy of Sciences of Ukraine, 235-240 (in Russian).

Smirnov, N. I. 2015. In Zin'ko, V. N. (ed.). Bosporskie issledovaniia (Bosporan Studies) XXXI. Kerch: Kerchenskaia gorodskaia tipografiia Publ., 25-111 (in Russian).

Terenozhkin, A. I., Mozolevsky, B. N. 1988. Melitopolskii kurgan (Melitopol Barrow). Kiev: "Naukova dumka" Publ. (in Russian).

Dahl, V. I. 1881. Tolkovyi slovar' zhivogo velikorusskogo iazyka (Explanatory Dictionary of the Living Great Russian Language). Vol. 2. Saint Petersburg, Moscow: "Volf, M. O.” Publ. (in Russian).

Chernenko, E. V. 1981. Skifskie luchniki (Scythian Archers). Kiev: "Naukova dumka" Publ. (in Russian).

Chernykh, E. M. 2019a. In Povolzhskaya arkheologiya (Volga River Region Archaeology) 27 (1), 136-149 (in Russian).

Chernykh, E. M. 2019b. In Arkheologiia Evraziiskikh stepei (Archaeology of Eurasian Steppes) 2, 227-245 (in Russian).

Chugunov, K. V. 2004. In Piotrovskii, M. B. (ed.). Arzhan. Istochnik v doline tsarei. Arkheologicheskie otkrytiia $v$ Tuve (Arzhan. Source in the Valley of the Kings. Archaeological Discoveries in Tuva). Saint Petersburg: "Slaviia" Publ., 10-37 (in Russian).

Shablavina, E. A. 2020. In Alekseev, A. Yu., Navrot, M, Gass, A., Piotrovskii, Yu. Yu. (eds.). Zhelezhyi vek. Evropa bez granits. Pervoe tysiacheletie do n.e. (Iron Age. Europe Without Borders. First Millennium BC). Saint Petersburg: "Chistyi list" Publ., 256-269 (in Russian).

Shul'ga, P. I. 2005. In Tishkin, A. A. (ed.). Snariazhenie kochevnikov Evrazii (Equipment of Eurasian Nomads). Barnaul: Altai State University, 183-189 (in Russian).

Shul'ga, P. I. 2015. Snariazhenie verkhovoi loshadi v Gornom Altae i Verkhnem Priob'e. Ch. II (VI-III vv. do n.e.). (Saddle Horse Gear in Mountain Altai and Upper Ob Area. Part II (6 $6^{\text {th }}-3^{\text {rd }}$ centuries B.C.). Novosibirsk: Novosibirsk State University Publ. (in Russian).

Smirnov, N. Yu. 2020. In S. Pankova, St. John Simpson (eds.). Masters of the Steppe: The Impact of the Scythians and Later Nomad Societies of Eurasia Proceedings of a conference held at the British Museum, 27-29 October 2017. London: Archaeopress Publ., 544-550.

\section{About the Author:}

Smirnov Nikolai Yu. Candidate of Historical Sciences, Institute for the History of Material Culture of the Russian Academy of Sciences. Dvortsovaya Emb., 18, Saint Petersburg, 191186, Russian Federation; ; kolaksais@yandex.ru

\section{О НЕКОТОРЫХ БРОНЗАХ ЗУЕВСКОГО МОГИЛЬНИКА}

Приложение 1

\section{(C) 2021 г. С.В. Хаврин}

Бронзовые изделия из погребения № 94 Зуевского могильника были исследованы методом рентгено-флюоресцентного анализа (РФА) на спектрометре ArtTAX (Brüker) в 2006 г. в Отделе научно-технологической экспертизы Государственного Эрмитажа.

Большинство металлических изделий из этого погребения выполнено из оловянистой бронзы с естественными примесями мышьяка (от следов до 4-6 \%) и свинца (от следов до 1-2\%). Количество олова в сплаве достигает 10-15\%. Наименее легированными, как это часто бывает, являются наконечники стрел, в них содержится от 1-2 \% до 2-4 \% олова. Два изделия выполнены из меди, но если в одном (медная накладка на железной бляшке) отмечено наличие тех же естественных примесей, что и у остальных изделий, то состав металла наконечника стрелы под инв. № 183 отличается полным их отсутствием.

Бронзы Зуевского могильника, как и другие бронзы ананьинской культуры ВолгоКамья, проанализировал ранее С.В. Кузьминых (Кузьминых, 1983). В указанной монографии дана их обобщенная публикация. Если следовать методике выделения химико-металлургических групп металла, предложенной Е.Н. Черныхом, то можно сказать, что среди бронз погребения № 94 преобладают 
бронзы волго-камской группы (ВК). Изделия из металла этой группы, характеризующейся повышенным содержанием мышьяка, свинца, сурьмы, серебра, преобладают в материалах всего могильника (Кузьминых, 1983, с. 42-46, рис. $23,24,25)$. Металл наконечника стрелы под инв. № 183 можно отнести к волго-уральской (ВУ) группе или к группе медистых песчаников (МП).

Недавно опубликованные результаты анализа бронз Зуевского могильника (Кузьминых, Орловская, 2017, табл. А, 12А, 12Б, c. 141-147) показали хорошую сходимость результатов анализа.
В составе изучаемого комплекса особый интерес представляет гривна, которая, по-видимому, при совершении погребения была сломана. Гривна сломана не в процессе археологических раскопок, поскольку металл ее практически не прокорродировал, а перед погребением. В процессе старой реставрации куски гривны спаяны свинцово-оловянным припоем. С целью проверки того, насколько легко было сломать гривну, из близкого по составу металла (медь с 10 \% олова) была вырезана полоска длиной 4 см. Оказалось, что металл достаточно легко ломается уже при изгибе $15-20^{\circ}$.

\section{ЛИТЕРАТУРА}

Кузьминых С.В. Металлургия Волго-Камья в раннем железном веке. М.: Наука, 1983, 257 с.

Кузьминых С.В., Орловская Л.Б. Металлургия Волго-Камья в раннем железном веке (медь и бронза): аналитические данные // Аналитические исследования лаборатории естественнонаучных методов. Вып. 4. М.: ИА РАН, 2017. С. 63-166.

Таблиия 1.

Результаты рентгено-флюоресцентного анализа бронзовых изделий из погребения № 94 Зуевского могильника*

\begin{tabular}{|c|c|c|c|c|c|c|c|}
\hline Погребение & Предмет & $C u$ & $A s$ & $S n$ & $P b$ & $S b$ & Прочие \\
\hline \multirow[t]{20}{*}{ № 94} & Наконечник стрелы № 181 & Осн. & $<1$ & $1-2$ & $<0,6$ & - & \\
\hline & Наконечник стрелы № 182 & Осн. & $<1$ & $2-4$ & $<1$ & - & \\
\hline & Наконечник стрелы № 183 & Осн. & - & - & - & - & \\
\hline & Наконечник стрелы № 184 & Осн. & $1-3$ & $2-4$ & Сл. & - & \\
\hline & Наконечник стрелы № 185 & Осн. & $1-3$ & $1-2$ & $<0,9$ & - & $\mathrm{Ag}$ \\
\hline & Бляшка биметаллич. № 190 & Осн. & Сл. & - & $<1$ & - & $\mathrm{Fe}, \mathrm{Ni}$ \\
\hline & Гривна № 191 & Осн. & Сл. & 9-12 & Сл. & $?$ & $\mathrm{Ag}, \mathrm{Zn}$ \\
\hline & Бляшка № 193 & Осн. & $<0,5$ & $10-15$ & $<0,5$ & - & $\mathrm{Zn}$ \\
\hline & Бляшка № 193 & Осн. & Сл. & 8-10 & Сл. & - & \\
\hline & Бляшка большая № 193 & Осн. & Сл. & $7-9$ & Сл. & Сл. & $\mathrm{Ag}, \mathrm{Zn}$ \\
\hline & Бляшка большая № 193 & Осн. & Сл. & $9-11$ & $<0,4$ & - & \\
\hline & Наконечник ремня № 194 & Осн. & Сл. & 9-12 & $<0,4$ & Сл. & \\
\hline & Наконечник ремня № 194 & Осн. & $<0,5$ & $10-15$ & $<0,6$ & Сл. & $\mathrm{Zn}$ \\
\hline & Застежка ремня № 195 & Осн. & $<0,9$ & 9-12 & $<1$ & Сл. & $\mathrm{Zn}$ \\
\hline & Распределитель № 195 & Осн. & $1-2$ & 3-5 & $<1$ & Сл. & $\mathrm{Ag}$ \\
\hline & Обойма № 198 & Осн. & $4-6$ & $7-10$ & $1-2$ & - & \\
\hline & Обойма № 198 & Осн. & $2-4$ & 3-6 & $1-2$ & - & \\
\hline & Подвеска № 199 & Осн. & $<0,4$ & 8-10 & Сл. & - & $\mathrm{Bi}$ \\
\hline & Пронизка спиральная № 201 & Осн. & $<0,4$ & 9-12 & $<0,7$ & Сл. & $\mathrm{Ag}$ \\
\hline & Пронизка спиральная № 201 & Осн. & $<1$ & $10-15$ & $<1$ & Сл. & \\
\hline
\end{tabular}

*Номера проанализированных изделий соответствуют их инвентарным номерам по коллекционной описи Государственного Эрмитажа (ГЭ, кол. 609). 